\title{
Gemcitabine and paclitaxel suppress the production of vascular endothelial growth factor induced by deferoxamine in human non-small cell lung cancer A549 cells
}

\author{
RYUJI IKEDA ${ }^{1}$, LEE C. VERMEULEN ${ }^{2}$, ZHISHENG JIANG $^{3}$, ELIM LAU $^{3}$ and JILL M. KOLESAR ${ }^{3}$ \\ ${ }^{1}$ Department of Clinical Pharmacy and Pharmacology, Graduate School of Medical and Dental Sciences, \\ Kagoshima University, Kagoshima, Japan; ${ }^{2}$ Division of Pharmacy Practice, \\ School of Pharmacy, University of Wisconsin-Madison and Center for Drug Policy, \\ University of Wisconsin Hospital and Clinics; ${ }^{3}$ School of Pharmacy, University of Wisconsin, and \\ University of Wisconsin Paul P. Carbone Comprehensive Cancer Center, Madison, WI, USA
}

Received May 27, 2010; Accepted July 19, 2010

DOI: $10.3892 / \mathrm{etm} .2010 .130$

\begin{abstract}
Vascular endothelial growth factor (VEGF) plays an important role in the process of angiogenesis in many types of cancer, including non-small cell lung cancer (NSCLC), and angiogenesis inhibitors and standard chemotherapy exhibit synergy though an unknown mechanism. We therefore hypothesized that cytotoxic chemotherapy influences VEGF production and analyzed VEGF production in an NSCLC A549 cell line after treatment with standard chemotherapy. Paclitaxel inhibited the production of VEGF in A549 cells, while cisplatin and erlotinib did not. Paclitaxel and gemcitabine inhibited deferoxamine (DFX) (known to mimic hypoxia)-induced VEGF production in A549 cells. Erlotinib also inhibited DFX-induced VEGF production in A549 cells slightly, while cisplatin did not. We subsequently examined the effect of the interaction between paclitaxel or gemcitabine and VEGF protein. Paclitaxel and gemcitabine did not directly affect the binding of VEGF. Since VEGF is known as one of the HIF-1 target genes, we examined the effect of paclitaxel and gemcitabine on HIF-1 $\alpha$ levels induced by DFX in A549 cells. Paclitaxel and gemcitabine inhibited DFX-induced HIF-1 $\alpha$ in A549 cells. These findings may be useful for future treatment schedules, including anti-cancer agents in NSCLC.
\end{abstract}

\section{Introduction}

Lung cancer is the leading cause of cancer-related death in developed nations. In the US, an estimated 219,440 new cases and 159,390 deaths were projected for $2009(1,2)$. Non-small

Correspondence to: Dr Ryuji Ikeda, Department of Clinical Pharmacy and Pharmacology, Graduate School of Medical and Dental Sciences, Kagoshima University, 8-35-1 Sakuragaoka, Kagoshima 890-8520, Japan

E-mail: ikeda@m.kufm.kagoshima-u.ac.jp

Key words: gemcitabine, paclitaxel, vascular endothelial growth factor cell lung cancer (NSCLC) commonly presents as incurable locally advanced or metastatic disease. Despite major research efforts, survival prospects remain dismally small, and 14\% of all patients with lung cancer are expected to live 5 years after diagnosis (3). Recent innovations to improve treatment for NSCLC have focused on targeted inhibitors, including the vascular endothelial growth factor (VEGF) inhibitor bevacizumab. Angiogenesis is a critical component for growth and the metastatic spread of tumors (4). Mediators of angiogenesis include VEGF, which is overexpressed in many malignancies, NSCLC among them. Expression of VEGF in tumor or serum has been linked to poor survival outcomes and response to therapy (1,5-9). In patients with advanced incurable NSCLC, cisplatin-based combinations have resulted in improved survival rates. Moreover, platinum combined with anti-cancer agents, such as paclitaxel, docetaxel, gemcitabine, vinorelbine or pemetrexed (3), in combination with bevacizumab, in bevacizumab-eligible patients, is recommended as first-line therapy for most patients (3). Both in vivo (10) and in vitro $(11,12)$ evaluations have demonstrated synergy between the VEGF inhibitor bevacizumab and cytotoxic chemotherapy, although the mechanism is unknown. Hanrahen et al recently demonstrated that the combination of paclitaxel and carboplatin decreased VEGF in vivo (13).

We hypothesized that bevacizumab chemotherapy synergy may result from the inhibition of VEGF. We therefore examined whether cisplatin, erlotinib, paclitaxel and gemcitabine affect the production of VEGF in NSCLC A549 cells.

\section{Materials and methods}

Reagents. A human VEGF immunoassay was obtained from R\&D Systems, Inc. (Minneapolis, MN, USA). Paclitaxel, deferoxamine and 3-[4,5-dimethyl-thiazol-2-yl]-2,5-diphenyl tetrazolium bromide (MTT) were obtained from Sigma Chemical Co. (St. Louis, MO, USA). Gemcitabine hydrochloride was from LKT Laboratories, Inc. (St. Paul, MN, USA). Erlotinib was from Chemie Tek (Indianapolis, IN, USA). Fetal bovine serum (FBS), Dulbecco's modified Eagle's medium 

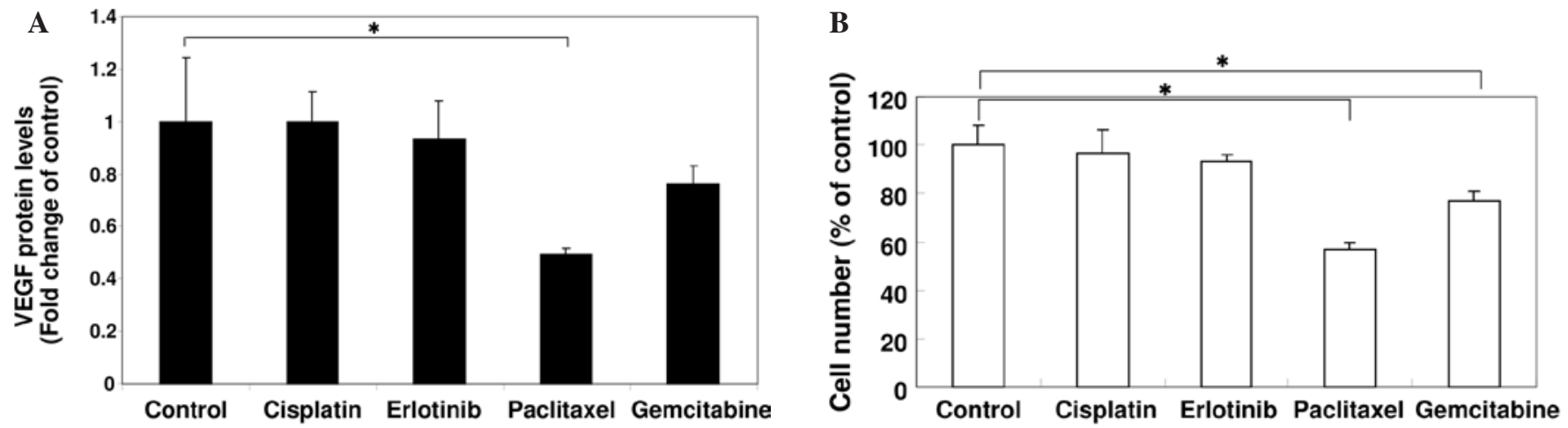

Figure 1. Effect of anti-cancer agents on the production of VEGF and cell proliferation. (A) A549 cells were cultured in serum-starved medium with or without $10 \mu \mathrm{M}$ cisplatin, $10 \mu \mathrm{M}$ erlotinib, $1 \mu \mathrm{M}$ paclitaxel or $1 \mu \mathrm{M}$ gemcitabine for $24 \mathrm{~h}$ as indicated. VEGF protein levels were measured using an ELISA assay. Data are the mean of triplicate experiments, and bars represent the mean $\pm \mathrm{SD}$. ${ }^{*} \mathrm{P}<0.05$. (B) A549 cells were cultured in serum-starved medium with or without $10 \mu \mathrm{M}$ cisplatin, $10 \mu \mathrm{M}$ erlotinib, $1 \mu \mathrm{M}$ paclitaxel or $1 \mu \mathrm{M}$ gemcitabine for $24 \mathrm{~h}$ as indicated. The effect of the agents on cell proliferation was examined using the MTT assay. Data are the mean of triplicate experiments, and bars represent the mean $\pm \mathrm{SD} .{ }^{*} \mathrm{P}<0.05$.

(DMEM), penicillin-streptomycin solution $(10,000 \mathrm{U} / \mathrm{ml}$ penicillin and $10,000 \mu \mathrm{g} / \mathrm{ml}$ streptomycin) were from Hyclone (Logan, UT, USA). Antibody against HIF-1 $\alpha$ was from BD Biosciences (San Jose, CA, USA).

Cell culture. The A549 cell line, derived from NSCLC, was maintained in DMEM containing 10\% FBS, $100 \mathrm{U} / \mathrm{ml}$ penicillin and $100 \mu \mathrm{g} / \mathrm{ml}$ streptomycin at $37^{\circ} \mathrm{C}$ in a $5 \% \mathrm{CO}_{2}$ humidified atmosphere.

Cell proliferation by 3-[4,5-dimethylthiazol-2-yl]-2,5diphenyl tetrazolium bromide (MTT) assay. Cell proliferation in vitro was measured by the MTT colorimetric assay in 96-well plates. The cells $\left(5 \times 10^{3}\right)$ were inoculated into each well. After overnight incubation $\left(37^{\circ} \mathrm{C}\right.$ in $\left.5 \% \mathrm{CO}_{2}\right)$, anti-cancer agents were added to the culture and were then incubated for $24 \mathrm{~h}$. Thereafter, $50 \mu \mathrm{l}$ of MTT $(1 \mathrm{mg} / \mathrm{ml})$ was added to each well, and the plates were incubated for an additional $4 \mathrm{~h}$. After aspiration of the culture medium, the resulting formazan was dissolved with $100 \mu \mathrm{l}$ of dimethylsulfoxide. The plates were read at $570 \mathrm{~nm}$ using a microplate reader.

Binding analysis of the effect of paclitaxel and gemcitabine on VEGF. To examine the effect of paclitaxel or gemcitabine on the binding of VEGF, $100 \mu \mathrm{l}$ of VEGF $(250 \mathrm{pg} / \mathrm{ml})$ was mixed with $100 \mu \mathrm{l}$ of paclitaxel (final concentrations: 1,10 and $100 \mu \mathrm{M}$ ) or gemcitabine (final concentrations: 1, 10 and $100 \mu \mathrm{M}$ ). After 1-h reaction periods, the concentrations of VEGF were detected with ELISA according to the manufacturer's guidelines.

Measurement of VEGF in conditioned media. The cells were plated in 96-well plates at $1 \times 10^{4}$ cells/well and cultured overnight. The growth medium was replaced with serum-free medium. These cells were routinely maintained at $37^{\circ} \mathrm{C}$ in a humidified atmosphere of $5 \% \mathrm{CO}_{2}$ for an additional $24 \mathrm{~h}$.

Protein extraction and immunoblotting. The cells were harvested and lysed with RIPA buffer [50 mM Tris- $\mathrm{HCl}$ (pH 8.0), $150 \mathrm{mM} \mathrm{NaCl}, 1 \%$ Nonidet P-40, 0.1\% SDS, $0.5 \%$ sodium deoxycholate, $1 \mathrm{mM}$ p-amidinophenyl methanesul- fonyl fluoride hydrochloride and $1 \mu \mathrm{g} / \mathrm{ml}$ aprotinin. Samples were subjected to $6 \%$ sodium dodecyl sulfate polyacrylamide gel electrophoresis (SDS-PAGE) according to the method of Laemmli. Proteins were electrophoretically transferred onto polyvinylidene difluoride membranes (Immobilon-P transfer membrane; Millipore, Bedford, MA, USA) using Bio-Rad Transblot SD apparatus. The membrane was treated with buffer A $[350 \mathrm{mM} \mathrm{NaCl}, 10 \mathrm{mM}$ Tris- $\mathrm{HCl}(\mathrm{pH} \mathrm{8.0)}$ and $0.05 \%$ Tween-20] containing 3\% skimmed milk for $1 \mathrm{~h}$ and incubated with the indicated antibody $(1: 1,000)$ in buffer $\mathrm{A}$ containing 3\% skimmed milk for $1 \mathrm{~h}$. Following four washes with buffer A (10 min each), the membrane was incubated with a peroxidase-conjugated horse anti-mouse IgG diluted 1:1,000 in buffer A containing 3\% skimmed milk for $1 \mathrm{~h}$. The membrane was washed with buffer A and developed using an enhanced chemiluminescence Western blotting detection system (Amersham Biosciences, Buckinghamshire, UK).

Statistical analysis. Differences between groups were tested by one-way ANOVA. Data are presented as the means \pm SD. Differences were considered significant at $\mathrm{P}<0.05$.

\section{Results}

Effect of anti-cancer agents on VEGF production in A549 cells. To investigate the effect of anti-cancer agents on the production of VEGF, A549 cells were treated with cisplatin, erlotinib, paclitaxel or gemcitabine for $24 \mathrm{~h}$, followed by ELISA analysis for VEGF. As shown in Fig. 1A, paclitaxel was capable of reducing the production of VEGF, while cisplatin and erlotinib did not affect production. Gemcitabine slightly suppressed the production of VEGF.

Effect of anti-cancer agents on A549 cell proliferation. To examine the effect of anti-cancer agents on the cell proliferation of A549 cells, we performed the MTT assay. A549 cells were cultured in DMEM media to eliminate the exogenous source of growth factors. As shown in Fig. 1B, cisplatin and erlotinib had no effect on A549 cell proliferation. Whereas paclitaxel inhibited cell proliferation, gemcitabine was less effective than paclitaxel $(\mathrm{P}<0.05)$. 


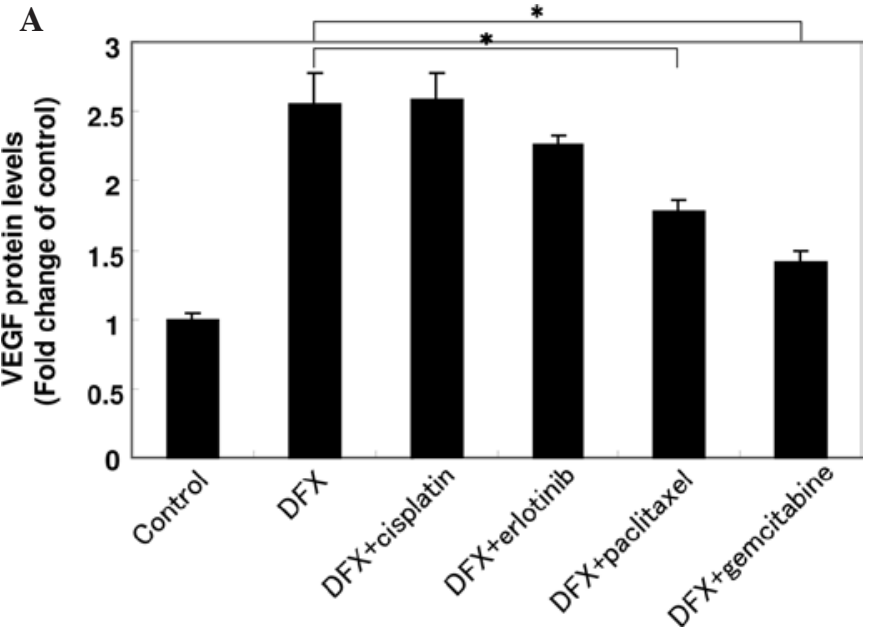

B

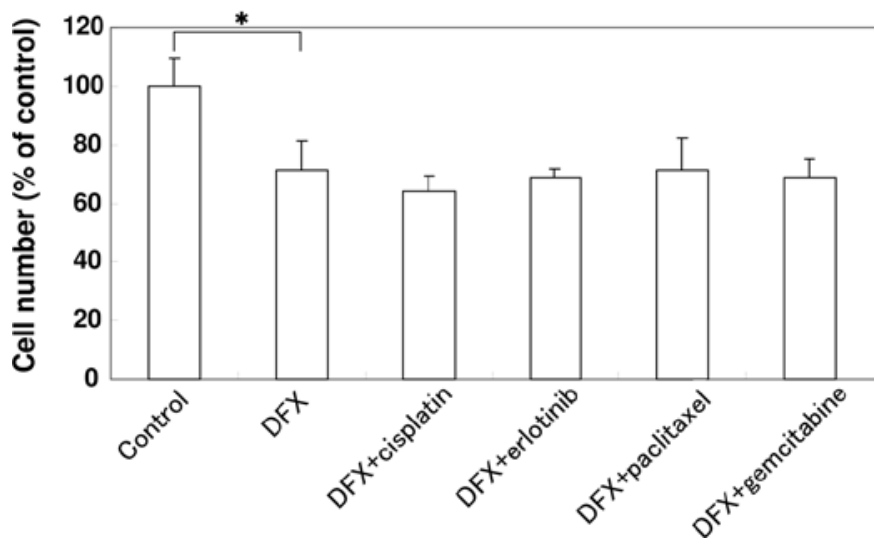

Figure 2. Effect of anti-cancer agents on the production of VEGF and cell proliferation in the presence of DFX in A549 cells. (A) A549 cells were cultured in serum-starved medium with or without $10 \mu \mathrm{M}$ cisplatin, $10 \mu \mathrm{M}$ erlotinib, $1 \mu \mathrm{M}$ paclitaxel or $1 \mu \mathrm{M}$ gemcitabine in the presence of $100 \mu \mathrm{M}$ DFX for $24 \mathrm{~h}$ as indicated. VEGF protein levels were measured using an ELISA assay. Data are the mean of triplicate experiments and bars represent the mean \pm SD. "P $<0.05$. (B) A549 cells were cultured in serum-starved medium with or without $10 \mu \mathrm{M}$ cisplatin, $10 \mu \mathrm{M}$ erlotinib, $1 \mu \mathrm{M}$ paclitaxel or $1 \mu \mathrm{M}$ gemcitabine in the presence of $100 \mu \mathrm{M}$ DFX for $24 \mathrm{~h}$ as indicated. The effect of the agents on cell proliferation was examined using the MTT assay. Data are the mean of triplicate experiments and bars represent the mean $\pm \mathrm{SD}$. ${ }^{*} \mathrm{P}<0.05$.

Effect of anti-cancer agents on VEGF production in A549 cells in the presence of deferoxamine. Expression of VEGF is up-regulated by hypoxic conditions in tumor cells and by the activation of oncogenes such as v-Src and Ras (14-16). To examine the effect of a hypoxic condition on the production of VEGF, A549 cells were exposed to deferoxamine (DFX). DFX is known as a hypoxia mimic agent and an iron chelator that depletes iron and inhibits oxygen, $\mathrm{Fe}^{2+}$ and oxoglutaratedependent dioxygenases (17). As shown in Fig. 2A, VEGF production levels were increased by DFX after $24 \mathrm{~h}$ in A549 cells. The cells treated with cisplatin did not affect VEGF production. Paclitaxel and gemcitabine suppressed the production of VEGF, although erlotinib was less effective than paclitaxel and gemcitabine $(\mathrm{P}<0.05)$.

Effect of anti-cancer agents on A549 cell proliferation in the presence of deferoxamine. To investigate the effect of anti-cancer agents on the proliferation of A549 cells in the presence of DFX, an MTT assay was performed. As shown in Fig. 2B, cell proliferation was inhibited by DFX, while the cells treated with DFX and chemotherapy were not inhibited to a greater extent than those treated with DFX alone. These results suggest that the inhibitory effect of paclitaxel and gemcitabine on VEGF production was independent of the proliferation of A549 cells.

Effect of paclitaxel and gemcitabine on the binding of VEGF. To investigate whether paclitaxel and gemcitabine interact with VEGF, $100 \mu \mathrm{l}$ of VEGF $(250 \mathrm{ng} / \mathrm{ml})$ was mixed with $100 \mu \mathrm{l}$ of paclitaxel (final concentrations: 1,10 and $100 \mu \mathrm{M}$ ) or gemcitabine (final concentrations: 1, 10 and $100 \mu \mathrm{M}$ ). Subsequently, the concentrations of VEGF were detected with ELISA. As shown in Fig. 3, paclitaxel and gemcitabine did not directly affect the binding of VEGF.

Effect of paclitaxel and gemcitabine on HIF-1 $\alpha$ expression induced by deferoxamine in A549 cells. VEGF is known as

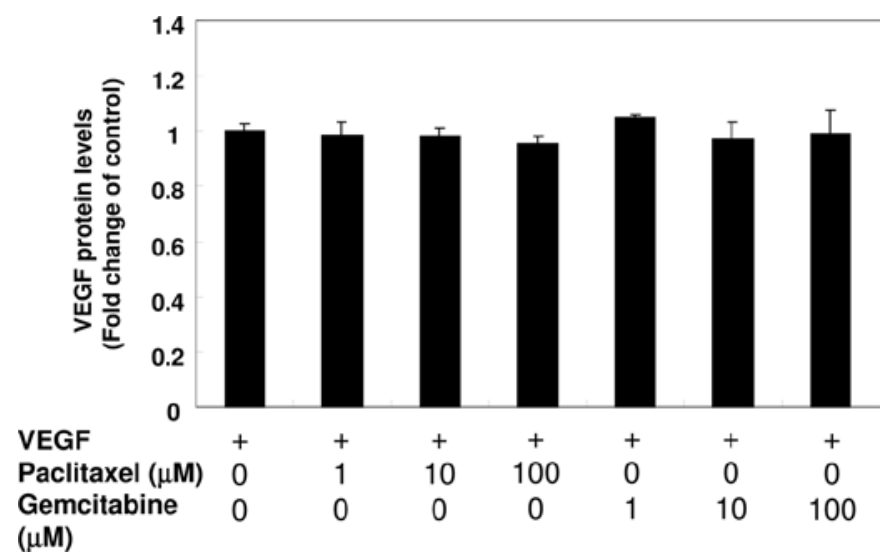

Figure 3. Effect of paclitaxel and gemcitabine on the binding of VEGF. Paclitaxel (final concentrations: 1,10 and $100 \mu \mathrm{M}$ ) or gemcitabine (final concentrations: 1,10 and $100 \mu \mathrm{M})$ were mixed with $100 \mu \mathrm{l}$ of $\operatorname{VEGF}(250 \mathrm{pg} /$ $\mathrm{ml}$ ). After 1-h reaction periods, the concentrations of VEGF were detected with ELISA according to the manufacturer's guidelines. Data are the mean of triplicate experiments, and bars represent the mean \pm SD.

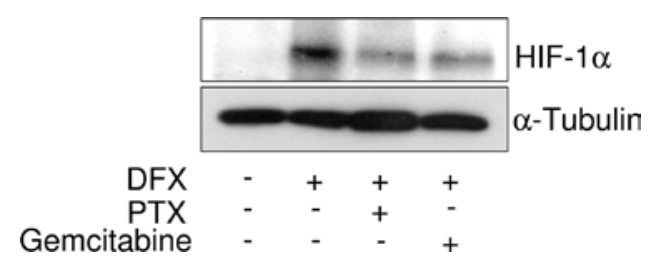

Figure 4. Effect of paclitaxel and gemcitabine on the expression of HIF-1a induced by DFX. A549 cells treated with deferoxamine (DFX) $(100 \mu \mathrm{M})$ were incubated in the presence of $1 \mu \mathrm{M}$ paclitaxel (PTX) or $1 \mu \mathrm{M}$ gemcitabine for $24 \mathrm{~h}$. HIF-1 $\alpha$ was detected by immunoblotting with anti-HIF-1 $\alpha$ antibody. Blotting of $\alpha$-tubulin was used as a loading control.

one of the HIF-1 target genes (18). We therefore determined the effect of paclitaxel or gemcitabine on the protein level of HIF-1 $\alpha$ induced by DXF in A549 cells. As shown in Fig. 4, 
the incubation of A549 cells in the presence of DXF resulted in a marked increase in HIF-1 $\alpha$ protein levels. Treatment with paclitaxel and gemcitabine substantially suppressed the induction of HIF-1 $\alpha$ in A549 cells in the presence of DFX.

\section{Discussion}

VEGF is a potent inducer of angiogenesis both in vivo and in vitro (19-21). Mutations of one or both alleles of the VEGF gene result in an embryonic lethal phenotype in mice due to inadequate vascularization, suggesting that VEGF is required for the early stages of vascular development $(22,23)$. Expression of VEGF is up-regulated in a variety of human tumors, including lung cancer, and VEGF-stimulated angiogenesis seems to be required for the development of solid tumors $(24,25)$. The inhibition of VEGF expression was in turn found to inhibit tumor angiogenesis in vivo and decrease tumor size in nude mice (26-28). VEGF has also been frequently evaluated in clinical trials of angiogenesis inhibitors and is accepted as a marker of drug activity. In this study, we demonstrated that gemcitabine and paclitaxel inhibited the production of VEGF in NSCLC A549 cells. This suggests that cytotoxic chemotherapy also reduces VEGF production, and that the inhibition of VEGF may be a mechanism by which synergy occurs between cytotoxic chemotherapy and angiogenesis inhibitors.

Paclitaxel is known to induce mitotic arrest and apoptosis by inhibiting the depolymerization of microtubules. Tumor growth and metastasis are affected by the metabolic rate and angiogenesis. Loo et al also reported that paclitaxel is an effective cytotoxic agent with possible anti-angiogenic effects (29).

Gemcitabine, a chemotherapeutic agent used in the treatment of advanced NSCLC, is an analogue of deoxycytidine and is phosphorylated to 5 -monophosphate by deoxycitidine kinase. It is then phosphorylated by uridylate-cytidylate monophosphate kinase to difluorodeoxycytidine 5-diphosphate, which interferes with the function of ribonucleotide reductase and reduces the pool of deoxyribonucleotide 5-phosphate available for DNA synthesis (30). Pre-treatment of transitional bladder cancer cell lines with VEGF antisense oligodeoxynucleotides may increase sensitivity to chemotherapy. Combination treatment with VEGF antisense oligodeoxynucleotides and anti-cancer agents, such as mitomycin $\mathrm{C}$, gemcitabine or cisplatin, was found to decrease the cell viability compared to nonsense oligodeoxynucleotide plus anti-cancer agents $(31,32)$. These results suggest that VEGF is an additional putative target for enhancing therapeutic benefit. The inhibition of VEGF by gemcitabine and paclitaxel also has novel potential use in anti-cancer drug therapy, and represents a novel method for inhibiting tumor angiogenesis in NSCLC tumorigenesis.

VEGF is known as one of the HIF-1 target genes, and HIF- $1 \alpha$ is rapidly degraded in normoxia by the ubiquitin proteasome pathway $(18,33)$. Polyubiquitination of HIF-1 $\alpha$ is mediated by the von Hippel-Lindau tumor suppressor (VHL), and VHL binding is controlled by hydroxylation of two proline residues (Pro-402 and Pro-564) in HIF-1 $\alpha$. These prolines are modified in normoxia by HIF prolyl-4-hydroxylase, which requires oxygen, iron and 2-oxoglutarate as co-factors. Depletion of oxygen or iron chelation inhibits enzyme activity, resulting in the stabilization of HIF-1 $\alpha$ (33). Further study is required to elucidate the mechanism of the inhibitory effect of gemcitabine and paclitaxel on HIF-1 $\alpha$ levels in NSCLC A549 cells.

In conclusion, our results demonstrate that paclitaxel and gemcitabine modulate angiogenesis by decreasing VEGF, even under conditions of hypoxia. These agents will aid in the design of future chemotherapy protocols for NSCLC patients.

\section{Acknowledgements}

At the time this research was conducted, Dr Ikeda was a visiting scholar at the School of Pharmacy, University of Wisconsin-Madison, and the University of Wisconsin Paul P. Carbone Comprehensive Cancer Center, Madison, WI, USA.

\section{References}

1. Crabb SJ, Patsios D, Sauerbrei E, Ellis PM, Arnold A, Goss G, Leighl NB, Shepherd FA, Powers J, Seymour L and Laurie SA: Tumor cavitation: impact on objective response evaluation in trials of angiogenesis inhibitors in non-small-cell lung cancer. $\mathrm{J}$ Clin Oncol 27: 404-410, 2009.

2. Jemal A, Siegel R, Ward E, Hao Y, Xu J and Thun MJ: Cancer statistics, 2009. CA Cancer J Clin 59: 225-249, 2009.

3. Azzoli CG, Baker S Jr, Temin S, et al: American Society of Clinical Oncology Clinical Practice Guideline update on chemotherapy for stage IV non-small-cell lung cancer. J Clin Oncol 27: 6251-6266, 2009.

4. Hanahan D and Weinberg RA: The hallmarks of cancer. Cell 100: 57-70, 2000.

5. Dudek AZ and Mahaseth H: Circulating angiogenic cytokines in patients with advanced non-small cell lung cancer: correlation with treatment response and survival. Cancer Invest 23: 193-200, 2005.

6. Laack E, Scheffler A, Burkholder I, Boeters I, Andritzky B, Schuch G, Görn M, Vohwinkel G, Edler L, Fiedler W and Hossfeld DK: Pretreatment vascular endothelial growth factor (VEGF) and matrix metalloproteinase-9 (MMP-9) serum levels in patients with metastatic non-small cell lung cancer (NSCLC). Lung Cancer 50: 51-58, 2005.

7. Nishi M, Abe Y, Tomii Y, Tsukamoto H, Kijima H, Yamazaki H, Ohnishi Y, Iwasaki M, Inoue H, Ueyama Y and Nakamura M: Cell binding isoforms of vascular endothelial growth factor-A (VEGF189) contribute to blood flow-distant metastasis of pulmonary adenocarcinoma. Int J Oncol 26: 1517-1524, 2005.

8. Seto T, Higashiyama M, Funai H, Imamura F, Uematsu K, Seki N, Eguchi K, Yamanaka T and Ichinose Y: Prognostic value of expression of vascular endothelial growth factor and its flt-1 and KDR receptors in stage I non-small-cell lung cancer. Lung Cancer 53: 91-96, 2006.

9. Shimanuki Y, Takahashi K, Cui R, Hori S, Takahashi F, Miyamoto $\mathrm{H}$ and Fukurchi Y: Role of serum vascular endothelial growth factor in the prediction of angiogenesis and prognosis for non-small cell lung cancer. Lung 183: 29-42, 2005.

10. Wagstaff AJ, Keam SJ and McCormack PL: Bevacizumab plus platinum-based chemotherapy: in advanced non-small cell lung cancer. BioDrugs 23: 187-196, 2009.

11. Dai M, Luo RC, Zheng DY, Lü CW and Ding XM: Effects of bevacizumab and cisplatin on human lung adenocarcinoma A549/DDP xenografts in nude mice. Nan Fang Yi Ke Da Xue Xue Bao 27: 1402-1405, 2007.

12. Lee FY, Covello KL, Castaneda S, Hawken DR, Kan D, Lewin A, Wen ML, Ryseck RP, Fairchild CR, Fargnoli J and Kramer R: Synergistic antitumor activity of ixabepilone (BMS-247550) plus bevacizumab in multiple in vivo tumor models. Clin Cancer Res 14: 8123-8131, 2008.

13. Hanrahan EO, Lin HY, Kim ES, Yan S, Du DZ, McKee KS, Tran HT, Lee JJ, Ryan AJ, Langmuir P, Johnson BE and Heymach JV: Distinct patterns of cytokine and angiogenic factor modulation and markers of benefit for vandetanib and/or chemotherapy in patients with non-small-cell lung cancer. J Clin Oncol 28: 193-201, 2010. 
14. Jiang BH, Agani F, Passaniti A and Semenza GL: V-SRC induces expression of hypoxia-inducible factor 1 (HIF-1) and transcription of genes encoding vascular endothelial growth factor and enolase 1: involvement of HIF-1 in tumor progression. Cancer Res 57: 5328-5335, 1997.

15. Rak J, Filmus J, Finkenzeller G, Grugel S, Marme D and Kerbel RS: Oncogenes as inducers of tumor angiogenesis. Cancer Metastasis Rev 14: 263-277, 1995.

16. Semenza GL: Hypoxia, clonal selection, and the role of HIF-1 in tumor progression. Crit Rev Biochem Mol Biol 35: 71-103, 2000.

17. López-Barneo J, del Toro R, Levitsky KL, Chiara MD and Ortega-Sáenz P: Regulation of oxygen sensing by ion channels. J Appl Physiol 96: 1187-1195, 2004.

18. Forsythe JA, Jiang BH, Iyer NV, Agani F, Leung SW, Koos RD and Semenza GL: Activation of vascular endothelial growth factor gene transcription by hypoxia-inducible factor 1 . Mol Cell Biol 16: 4604-4613, 1996.

19. Ferrara N and Bunting S: Vascular endothelial growth factor, a specific regulator of angiogenesis. Curr Opin Nephrol Hypertens 5: 35-44, 1996

20. Folkman J: Angiogenesis in cancer, vascular, rheumatoid and other disease. Nat Med 1: 27-31, 1995.

21. Neufeld G, Cohen T, Gengrinovitch S and Poltorak Z: Vascular endothelial growth factor (VEGF) and its receptors. FASEB J 13: 9-22, 1999.

22. Carmeliet P, Moons L, Dewerchin M, Mackman N, Luther T, Breier G, Ploplis V, Muller M, Nagy A, Plow E, Gerard R, Edgington T, Risau W and Collen D: Insights in vessel development and vascular disorders using targeted inactivation and transfer of vascular endothelial growth factor, the tissue factor receptor, and the plasminogen system. Ann NY Acad Sci 811: 191-206, 1997

23. Ferrara N, Carver-Moore K, Chen H, Dowd M, Lu L, O'Shea KS, Powell-Braxton L, Hillan KJ and Moore MW: Heterozygous embryonic lethality induced by targeted inactivation of the VEGF gene. Nature 380: 439-442, 1996.

24. Olson TA, Mohanraj D, Carson LF and Ramakrishnan S: Vascular permeability factor gene expression in normal and neoplastic human ovaries. Cancer Res 54: 276-280, 1994.
25. Senger DR, van de Water L, Brown LF, Nagy JA, Yeo KT, Yeo TK, Berse B, Jackman RW, Dvorak AM and Dvorak HF: Vascular permeability factor (VPF, VEGF) in tumor biology. Cancer Metastasis Rev 12: 303-324, 1993.

26. Holash J, Davis S, Papadopoulos N, et al: VEGF-Trap: a VEGF blocker with potent antitumor effects. Proc Natl Acad Sci USA 99: 11393-11398, 2002.

27. Kim KJ, Li B, Winer J, Armanini M, Gillett N, Phillips HS and Ferrara N: Inhibition of vascular endothelial growth factorinduced angiogenesis suppresses tumour growth in vivo. Nature 362: 841-844, 1993.

28. Prewett M, Huber J, Li Y, Santiago A, O'Connor W, King K, Overholser J, Hooper A, Pytowski B, Witte L, Bohlen P and Hicklin DJ: Antivascular endothelial growth factor receptor (fetal liver kinase 1) monoclonal antibody inhibits tumor angiogenesis and growth of several mouse and human tumors. Cancer Res 59: 5209-5218, 1999.

29. Loo WT, Fong JH, Cheung MN and Chow LW: The efficacy of paclitaxel on solid tumour analysed by ATP bioluminescence assay and VEGF expression: a translational research study. Biomed Pharmacother 59 (Suppl 2): 337-339, 2005.

30. Plunkett W, Huang P, Xu YZ, Heinemann V, Grunewald R and Gandhi V: Gemcitabine: metabolism, mechanisms of action, and self-potentiation. Semin Oncol 22: 3-10, 1995.

31. Krause S, Förster Y, Kraemer K, Fuessel S, Kotzsch M, Schmidt U, Wirth MP, Meye A and Schwenzer B: Vascular endothelial growth factor antisense pretreatment of bladder cancer cells significantly enhances the cytotoxicity of mitomycin C, gemcitabine and cisplatin. J Urol 174: 328-331, 2005.

32. Förster Y, Meye A, Krause S and Schwenzer B: Antisensemediated VEGF suppression in bladder and breast cancer cells. Cancer Lett 212: 95-103, 2004.

33. Maxwell PH and Ratcliffe PJ: Oxygen sensors and angiogenesis. Semin Cell Dev Biol 13: 29-37, 2002. 